\title{
Exploring Partnerships for Social Innovation
}

\author{
Mario Risso*
}

\begin{abstract}
Even prior to the recent financial and economic slowdown many enterprises had adopted Corporate Social Responsibility (CSR) strategies to improve their relationships with customers, who are becoming more and more sensible to ethical values.

Recently, companies are increasingly promoting social innovation through collaborative initiatives among business, non-profit organizations (NPO) and public institutions for improving CSR implementation strategies. Often, innovation stems from this new trend based on the cross-fertilization between economic and social actors.

This article investigates how large retailers are shaping new approaches where economic and social aspects become mutually supportive to enhance their impact on local communities. The cases of 'solidarity stores' in France is an example of emerging innovation through contamination.
\end{abstract}

Keywords: Corporate Social Responsibility; Local Communities; ProfitNonProfit-Public Partnership; Solidarity Store; Food Waste; Large Retailers

\section{CSR and Social Innovation through Profit-Nonprofit-Public Partnerships}

Corporate Social Responsibility has become an important aspect of business strategies and activities (Brondoni 2003; Pepe 2007; Lambin 2009). So far, the literature has focused on various dimensions and measurement criteria of CSR. While CSR has been associated with innovation (McWilliams, Siegel 2000; Moore, Spence 2006; Husted, Allen 2007) this relationship still needs to be fully investigated as theoretical and empirical research remains limited.

In recent times, some authors have developed studies on CSR initiatives that have demonstrated how social innovation can be generated through collaborative approaches between profit and NPOs (Setainidi, Crane 2009; Selsky, Parker 2010). The inter-organizational collaboration is fast becoming a crucial source of innovation in advanced economies (Chesbrough 2003; Faems et al. 2005; Child et al. 2005; Faulkner, 2006, Sarkis et al. 2010). Innovation management studies highlight the importance of interacting with a different range of stakeholders to pool various knowledge and skills that promote innovation (Pittaway et al. 2004).

*Associate Professor of Management, Niccolò Cusano University, Rome (mario.risso@ unicusano.it)

Edited by: ISTEI - University of Milan-Bicocca

ISSN: 1593-0319

Risso Mario (2012) Exploring Partnerships for Social Innovation, Symphonya. Emerging Issues in Management (symphonya.unimib.it), n. 2, pp. 26-36

http://dx.doi.org/10.4468/2012.2.03risso 
Nowadays weak signals from non-core activities may become a source of continued innovation and competitive advantage (Day, Schoemaker 2006). Detecting weak signals is an activity clearly associated with developing organizational capabilities which may lead to new business models and social entrepreneurship (Holmes, Smart 2009). That's why, companies are beginning to pay more attention to the implementation of CSR strategies by partnerships with nonprofit organizations.

According to Holmes and Smart $(2009$, 395) "NPOs are emerging as major stakeholders in the business arena, as the traditional antagonism of nonprofits towards businesses is replaced with collaborations to address environmental and social issues through corporate responsibility mandates". Recent research in the field of CSR shows the importance of delivering organizational performance through innovative initiatives driven by businesses in response to social issues, bridging and bonding activities with nonprofits and public agencies.

An inter-organizational collaboration has expanded beyond individual organizations to better address complex societal challenges for which awareness is growing among large companies, institutions and civil society (Waddock 2008; Nambisan 2009). Hybrid organizations can be more effective and enduring than traditional organizations in meeting social challenges, mixing objectives that are simultaneously market-driven and value-driven (Boyd et al. 2009). In particular Selsky and Parker (2010) assert that businesses recently have been encouraged to play explicitly pro-social roles and that "rather than being social-need driven, such organizations may be social-innovation driven".

Businesses may consider social challenges as opportunities for building new business models that create shared value for companies and society addressing simultaneously market and social needs (Christensen et al. 2006; Porter, Kramer 2006; 2011). This means that companies can be able to intercept unexpressed needs or provide products and services for low-income people. Likewise, NPOs and public agencies may consider social challenges as opportunities for creating new service models.

Business-NPO partnerships represent the alignment of strategic business interests with societal expectations (Seitanidi 2007). "Such partnerships therefore offer considerable insight into the dynamics of CSR implementation, not least because business-NPO partnerships are typically seen by both sets of institutions as instantiations of 'doing' CSR" (Seitanidi, Crane 2009, 414).

Theoretical and practical studies have shown how for profit and non-profit organizations come together - despite their differences - to generate social value (Hess et al. 2002; Selsky, Parker 2005). Four basic models of partnership platforms have been identified (Selsky, Parker 2011):

- partnerships between nonprofit organizations and businesses;

- partnerships between governments and businesses;

- partnerships between governments and nonprofit organizations;

- tripartite partnerships (profit, nonprofit and public institutions).

These partnerships may evolve over time with different forms. They transcend the traditional boundaries of organizations, sectors and countries, and they enable a wider range of ideas, better use of resources, and faster solutions than traditional, monolithic entities (Nambisan 2009). They involve a commitment of resources time and effort - by individuals from all partner organisations. Participants work cooperatively to solve problems that affect them all and they make a commitment of 
financial and human resources requiring active rather than passive involvement (Waddock 1988).

Against this backdrop, tripartite partnerships are emerging as facilitators for social innovation and developers of sustainable business (Figure 1). The following sections seek to provide an example of emerging social innovation resulting from businessnonprofit-public partnership by investigating the implementation of recent CSR initiatives in the food retail sector in France.

In particular, section 2 presents a new way to approach CSR in food retail sector considering economic, environmental and social issues simultaneously. In this section, efforts to minimise food-waste and support low-income people are investigated. Finally, in section 3 some conclusions, limitations and future research needs are discussed.

Figure 1: Profit-Non-Profit-Public Partnership for Social Innovation

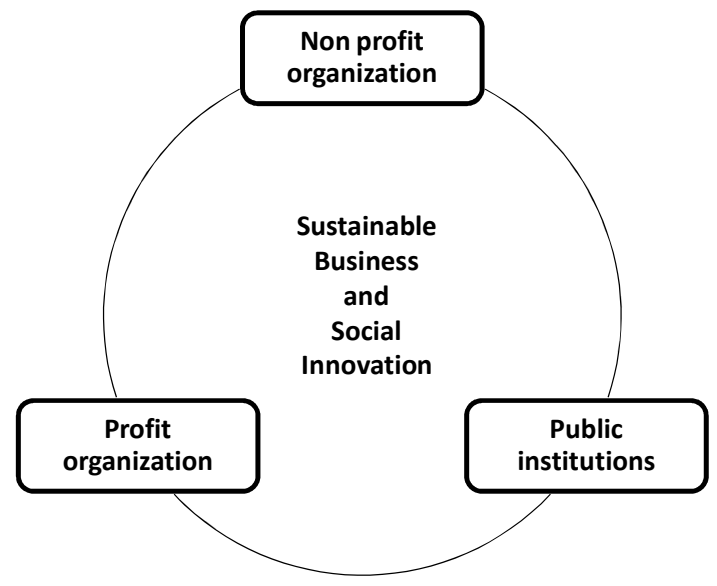

\section{New Ways to Implement CSR Initiatives in the Food Retail Sector}

Key international retailers have started to offer ethical products and services, consolidating their approach to CSR through activities related to sustainable development and a balanced distribution of value among all subjects affected by their activities (Whysall 2000; Pepe 2003; Jones et al. 2005; Musso, Risso 2006; Lee et al. 2009; Tassinari 2010). In such a way, they are trying to implement CSR initiatives towards both the upstream (suppliers) and downstream (customers) levels of their supply chains (Pepe 2003).

On the downstream side, there is limited analysis of retailers' CSR policies related to the support of local customers' communities, despite the fact that consumers are key stakeholders for retailers and that, to a large extent, they play a prominent role in the corporate social responsibility of the retailers (Jones, Comfort, Hiller 2007). The social initiatives of the large retailers that directly support local communities are mainly related to educational programs, donations and philanthropic support of charity organizations and employee volunteerism. Large retailers also promote 
cause-related marketing initiatives by connecting brands, products and their stores to a social cause, often by providing a certain percentage of income to local community organizations in the areas in which they operate.

This type of CSR efforts on the downstream side of the supply chain might not be directly recognized by customers. Simple donations to local charities, which require a relatively low contribution from retailers, are perceived as less 'socially responsible' than those activities that generate both a benefit to society and a high level of involvement from retailers (Van Herpen et al. 2003). This explains why retail companies are increasingly engaging in new forms of collaborative initiatives benefiting consumer communities (Jones et al. 2007; Lai et al. 2010).

Recently some large food retailers have gone far beyond basic and traditional philanthropy by better integrating their activities into the local communities they serve. This has helped them become more rooted in the community and accepted as a valued local partner. At the same time, if large retailers succeed in highlighting the community-oriented nature of the company, they could build brand support and improve the communication of their social programs (Lee et al. 2009). Consumers shopping at such stores are more receptive to CSR programs, and experience significant increases in their level of satisfaction and loyalty (Gupta, Pirsch 2008).

In order to be successful, retailers should look at ways to maximize their positive impact on communities, prioritizing those initiatives that are most relevant to their core business, employees and customers. The more innovative large retailers are shifting from mere philanthropic programs that create limited value to the development of partnerships with local NPOs based on a sustainable economic model.

\subsection{Towards Sustainable Practices for Minimising Food Waste}

In an effort to promote sustainable practices, some large food retailers are trying to identify solutions to increase awareness about food waste, reduce the rate of hunger experienced by low-income people, as well as the logistic cost of disposal waste.

The causes of food waste in medium/high-income countries are mainly related to consumer behaviour as well as to a lack of coordination between different actors in the supply chain (Sinha 2011). Economically avoidable food waste has a direct and negative impact on low-income consumers. Given that many consumers live on the margins of food insecurity, the optimisation of food waste practices could have an immediate and significant impact on their livelihoods. For poor consumers (food insecure or at-risk households), the priority is clearly to have access to food products that are nutritious, safe and affordable (Stuart 2009; Gustavsson et al. 2011).

Retail activities often carry out trimmings due to insufficient purchase planning, expiring 'best before' dates, or accidents that cause changes in weight, shape or form, and damage to the packaging of products during sales operations. Food trimmings, in some cases, are still safe, tasty and have good nutritional value, and they could be used for human consumption, but are usually disposed of. Some large retailers are promoting initiatives on prevention of food waste by also donating food for human aid purposes, but managing unsellable food at the store level could prove very difficult (Stenmarck et al. 2011). The hygiene requirements are very strict and many retail shops do not dare to donate food for food aid purposes. 
Retailers need clear working methods for food donation and donations need to be conducted in cooperation with specific organizations (charity, etc.) and authorities. When a single retailer takes this initiative, it is an action that also is associated with some problems due to the fact that the shop is continuously responsible for the food - meaning that if the food is bad, the shop might face problems. This can be avoided by making this handling more centralised via 'food banks', like those that are in Denmark (Danska Fødevarebanken), Italy (Banco Alimentare), Sweden (Allwin) and a number of other European countries, as well as in the USA (Salhofer et al. 2008; Stuart 2009).

The recent development of 'solidarity stores' to avoid food waste and help lowincome people is an interesting CSR initiative that represent an innovative sustainable way to deal with social problems by developing a profit-nonprofit partnership. Retail and charity organizations are arranging 'solidarity stores' for the collection, sale, or use of discarded 'sub-standard' products that are still safe, good and have nutritional value.

\subsection{The Solidarity Store}

Solidarity stores are local convenience stores where low-income people (poor people, unemployed and retired people with a low pension, etc.) who can't afford to buy their food in 'traditional' supermarkets, but who are, on the other hand, reluctant to benefit from charity, can buy everyday food products at around 10 or $20 \%$ of their 'normal price'.

A solidarity store is similar to a traditional store but it benefits from food donation, funds given and know-how transfer by local authorities, associations (e.g. Food Bank and Red Cross), foundations and companies, through local or national partnerships.

When solidarity stores were first created in France in the 1980s, solidarity stores were mainly partnerships between public institutions and nonprofit organizations meant to complete a system of free food distribution, essentially for homeless or very poor people.

After the last financial crisis, these initiatives have further developed with the active engagement of some large food retailers. Large retailers are playing a special role in developing this essential network of different partners allowing a rapid increase of the number and efficiency of solidarity stores available in France. In France, ANDES is a national network of solidarity stores which aims to 'fight against exclusion by and sustainable reintegration without promoting the assistantship').

Solidarity stores require effective and efficient logistics and sales management systems, which are better developed in cooperation among retailers, charity and other local institutions. With the involvement of large retailers, the model of solidarity stores has evolved towards the establishment of a tripartite partnership. These solidarity stores are becoming an innovative system to solve environmental and 
social problems in a sustainable manner and, at the same time, they are also innovative tools for improving CSR strategies of large retailers in a local community.

Against this backdrop, Carrefour and Auchan are a good example of large retailers which are engaged in supporting solidarity stores especially in their domestic markets.

Carrefour has promoted eight stores in France, several solidarity stores in Belgium and a few in Greece supported by the Carrefour International Foundation (Leboulenger 2010).

Simply Market, the supermarket of the group Auchan, decided in 2009 through the Simply Foundation to establish contacts with the network ANDES. At the end of 2010, 12 solidarity stores managed in partnership by Simply Market and ANDES were opened (Caussil 2010).

Full pallets of products with a small defect, or fresh products arriving just days before the expiration date, are sent to the solidarity store. The large retailer also donates equipment (gondolas, cool furniture, etc.), and know-how promoting training periods for solidarity stores employees in several professional areas (merchandising, promotion of fruit and vegetables, food safety, hygiene, conservation products, etc.).

Given the short shelf life of products and the need to meet quality standards, specific management, logistical and sale skills are required. Large retailers can bring those valuable competencies and managerial skills that once transferred to the network of partner association of solidarity stores (e.g. ANDES) allow for cost reduction and the maintenance of a fast cycle process. The partnership with a large food retailer enables the association of solidarity stores to develop logistical platforms and procedures through which food products are efficiently collected and managed.

Large retailers further provide financial support for the pre-financing of the warehouse and handling costs.

Nonprofit organizations (especially ANDES) and public local authorities add value in providing the know-how (relational and administrative) to interact with lowincome people and families affected by poverty. Public local authorities set the conditions for having access to social stores on the basis of socioeconomic and family criteria (age, number of children, etc.). Generally, people's income is close to the poverty line, but each structure defines its own criteria depending on the local social context.

The success of these partnerships is also due to the combination of personnel from different entities and with various backgrounds. Teams consist of employees of large retailers and NPOs which work together to launch the store by bringing their respective skills (fondationsimply.org).

Large retailers, nonprofit organizations and local public institutions participate in the financing, development and opening of new stores, including the rehabilitation of buildings and shop equipments.

The sales proceeds contribute to cover operational costs. Products from different large retailers can be sold in the same solidarity store managed by local nonprofit organizations. 


\subsection{Benefits and Drawbacks of Solidarity Store Partnerships}

As Guillaume Bapst, the director of the Andes puts it: "These partnerships between large retailers and ANDES are having consequences that one could hardly imagine" (Caussil 2010). Indeed, this example of profit-nonprofit-public partnership is producing simultaneously positive impacts for all parties involved.

The benefits of such partnership initiatives are significant (Table 1) but efficiency and impact on local communities should be improved. In order to bring benefits to scale, the pool of retailers, NPOs and public authorities partnering in the solidarity stores' network should be expanded to include a more significant number of actors, currently still limited.

Within the context of the current economic crisis, the involvement of large retailers seems to be key to ensure that solidarity stores are structured and managed in a way that is economically viable.

Table 1: Benefits from Solidarity Store Partnerships

\begin{tabular}{|c|c|}
\hline Large Retailers & NPOs and Local Communities \\
\hline $\begin{array}{l}\text { - Increased motivation of employees } \\
\text { through their involvement in new social } \\
\text { partnerships } \\
\text { - Enhancement of corporate brand image: } \\
\text { - providing services and products to } \\
\text { meet daily-life social needs of the } \\
\text { customers' communities } \\
\text { - reducing pollution } \\
\text { - Reduce cost to manage waste } \\
\text { - Avoid throwing unsold, but still safe } \\
\text { products }\end{array}$ & $\begin{array}{l}\text { - Support to low income families providing } \\
\text { cheaper products ( }-80 \% \text { of the normal price) } \\
\text { - Opportunity for professional training of } \\
\text { NPOs } \\
\text { - Improving of logistics and supply activities } \\
\text { for social stores' networks } \\
\text { - Create opportunities for job creation for local } \\
\text { community members promoting internships } \\
\text { and hiring preferences. }\end{array}$ \\
\hline
\end{tabular}

\section{Emerging Issues}

This work analyses an example of partnership established among nonprofit organizations, public institutions and large retailers in which economic and social aspects are mutually supportive. Through such collaborative initiatives, social operators benefit from the managerial skills to improve the efficiency of their project while business companies integrate ethical and social values into their corporate culture and maximise positive impact associated with their core-business.

If retailers want to be regarded as socially responsible, they must create the ìrightì connections between CSR initiatives and local customer communities to reshape their brand image and improve their long term competitiveness.

Partnerships between business, nonprofit organizations and public agencies constitute a recent addition to the forms of interaction between profit and the third sector. The involvement of the firm in supporting local communities has gradually shifted from philanthropic relationships between the two sectors (philanthropic stage) and transactional models (sponsorship, licensing, cause-related marketing, 
etc.) to a higher level of interactions, which is characterised by an integrative/relational type of the relationship.

Partnerships can contribute to the development of organizational (internal perspective) and institutional (external perspective) trust if the partners articulate clearly their motivation to join the initiative and respect the limitations of both the social and business logic behind the form of partnership adopted (Seitanidi, Ryan 2007).

In this way Carrefour and Auchan supports 'solidarity stores': a good example of economic, environmental and social initiative to improve CSR commitment and results.

Both examples illustrate that working in partnership with the third sector, local public institutions, consumers and other stakeholders can encourage innovative CSR approaches of large retailers and the adoption of best practices for development of the local communities. These emerging initiatives are rapidly expanding and the efforts to invest in local business will probably continue. Indeed, large retailers are intensifying the implementation of similar initiatives beyond domestic markets.

This study reveals an increasing interest of some large retailers and NPOs in promoting sustainable projects to foster local communities that aim to entrench sustainability into their daily core-business operations. A new shared management model reflecting the contamination between economic and social aspects for social innovation is emerging. However, the paper is an exploratory study and presents indications resulting from a desk analysis based on information and documentation available from academic journals, specialized magazines, company reports and websites. Data collected are limited, thus any conclusions drawn from these early results cannot be extended on a larger scale; rather they offer examples of promising CSR initiatives of large retailers implemented in collaboration with social stakeholders and public authorities. Additional research is needed to fully investigate the objectives, models, tools and practices used by large retailers and their partners to develop similar initiatives.

\section{Bibliography}

Brondoni Silvio M. (2003) Network Culture, Performance \& Corporate Responsibility, Symphonya Emerging issues in Management (symphonya.unimib.it) n.1, pp. 8-24. http://dx.doi.org/10.4468/2003.1.02brondoni

Boyd B., Henning N., Reyna E., Wang D. E and Welch M. D. (2009) Hybrid Organizations: New Business Models for Environmental Leadership, Greenleaf Publishing, Sheffield, UK.

Caussil J.N. (2010) Simply market s'implique avec les epiceries solidaires, LSA - Libre Service Actualité, 2 Décembre.

Chesbrough H. (2003) The Era of Open Innovation, MIT Sloan Management Review, vol. 44, n. 3, pp. 35-41.

Child J., Faulkner D., Tallman S. B. (2005) Cooperative Strategy. Managing Alliances, Networks, and Joint Ventures, Oxford Univ. Press, Oxford, $2^{\text {nd }}$ ed., UK.

Christensen C., Baumann H., Ruggles R., Sadtler T. (2006) Disruptive Innovation for Social Change, Harvard Business Review, December, pp. 94-101.

Day G., Schoemaker P. (2006) Peripheral Vision: Detecting the Weak Signals That Will Make or Break Your Company, Harvard Business School Press, Cambridge, MA. 
Faems, D., Van Looy B., Debackere, K. (2005) Interorganizational Collaboration and Innovation: Toward a Portfolio Approach, Journal of Product Innovation Management, vol. 22, n. 3, pp. 238250. http://dx.doi.org/10.1111/j.0737-6782.2005.00120.x

Faulkner D.O. (2006) Cooperative strategy. Strategic Alliances and Networks, in Faulkner D.O., Campbell A. (eds.), The Oxford Handbook of Strategy, Chapter 21, Oxford Univ. Press, Oxford, pp. 610-48.

Ganesan S., George M., Jap S., Palmatier R.W., Weitz B. (2009) Supply Chain Management and Retailer Performance: Emerging Trends, Issues, and Implications for Research and Practice, Journal of Retailing, vol. 85, n. 1, pp. 84-94. http://dx.doi.org/10.1016/j.jretai.2008.12.001

Gupta S., Pirsch J. (2008) The Influence of a Retailer's Corporate Social Responsibility Program on Re-conceptualizing Store Image, Journal of Retailing and Consumer Services, vol. 15, n. 6, pp. 516-526. http://dx.doi.org/10.1016/j.jretconser.2008.02.003

Gustavsson J., Cederberg C., Sonesson U., Van Otterdijk R., Meybeck A. (2011) Global Food Losses and Food Waste, Extent, Causes and Prevention, FAO, Rome.

Hess D., Rogovsky N., Dunfee T. W. (2002) The Next Wave of Corporate Community Involvement: Corporate Social Initiatives, California Management Review, vol. 44, n. 2, pp. 110-125.

Hill H. (2008) Food Miles: Background and Marketing, ATTRA. Available at www.attra.ncat.org/attra-pub/PDF/foodmiles.pdf.

Holmes S., Smart P. (2009) Exploring Open Innovation Practice in Firm-Nonprofit Engagements: a Corporate Social Responsibility Perspective, $R \& D$ Management, vol. 39, n. 4, pp. 394-409. http://dx.doi.org/10.1111/j.1467-9310.2009.00569.x

Husted B.W., Allen D.B. (2007) Corporate Social Strategy in Multinational Enterprises: Antecedents and Value Creation, Journal of Business Ethics, vol. 74, pp. 34-361. http://dx.doi.org/10.1007/s10551-007-9511-4

Jones, P., Comfort D., Eastwood I. (2005) Retailers and Sustainable Development in the UK, International Journal of Retail \& Distribution Management, vol. 33, n. 3, pp. 207-14. http://dx.doi.org/10.1108/09590550510588370

Jones P., Comfort D., Hillier D. (2007) What's in Store? Retail Marketing and Corporate Social Responsibility, Marketing Intelligence \& Planning, vol. 25, n. 1, pp. 17-30. http://dx.doi.org/10.1108/02634500710722371

Jones P., Wynn M., Comfort D., Hillier D. (2007) Corporate Social Responsibility and UK Retailers, Issues in Social \& Environmental Accounting, vol. 1, n. 2, pp. 243-257.

Lai K., Cheng T.C.E., Tang A.K.Y. (2010) Green Retailing: Factors for Success, California Management Review, vol. 52, n. 2, pp. 6-31.

Lambin J.J. (2009) Capitalism and Sustainable Development, Symphonya. Emerging Issues in Management (symphonya.unimib.it), n. 2, pp. 3-9.

http://dx.doi.org/10.4468/2009.2.02lambin

Leboulenger S. (2010) Carrefour soutient une huitième epicerie solidaire, LSA - Libre Service Actualité, 14 Janvier.

Lee M.Y., Fairhurst A., Wesley S. (2009) Corporate Social Responsibility: A Review of the Top 100 US Retailers, Corporate Reputation Review, vol. 12, pp. 140-158. http://dx.doi.org/10.1057/crr.2009.10

McWilliams A., Siegel D.S. (2000) Corporate Social Responsibility and Financial Performance: Correlation or Misspecification?, Strategic Management Journal, vol. 21, n. 5, pp. 603-609. http://dx.doi.org/10.1002/(SICI)1097-0266(200005)21:5<603::AID-SMJ101>3.0.CO;2-3

Moore G., Spence L. (2006) Editorial: Responsibility and Small Business, Journal of Business Ethics, vol. 67, pp. 219-226. http://dx.doi.org/10.1007/s10551-006-9180-8

Musso F., Risso M. (2006) CSR within Large Retailers International Supply Chains, Symphonya Emerging Issues in Management (symphonya.unimib.it), n. 1, pp. 79-92. 
http://dx.doi.org/10.4468/2006.1.06musso.risso

Nambisan S. (2009) Platforms for Collaboration, Stanford Social Innovation Review, vol. 7, n. 3, pp. 44-49.

Pepe C. (2007) Corporate Values in Global Supply Chains, Symphonya Emerging Issues in Management, (symphonya.unimib.it), n. 2, pp. 5-11.

http://dx.doi.org/10.4468/2007.2.02pepe

Pepe C. (2003) Global Retailers and Corporate Responsibility, Symphonya Emerging Issues in Management (symphonya.unimib.it), n. 1, pp. 55-71.

http://dx.doi.org/10.4468/2003.1.06pepe

Pittaway L., Robertson, M., Munir K., Denyer D., Neely A. (2004) Networking and Innovation: a Systematic Review of the Evidence, International Journal of Management Reviews, vol. 5/6, $\mathrm{n}$. 3/4, pp. 37-168. http://dx.doi.org/10.1111/j.1460-8545.2004.00101.x

Porter M., Kramer M (2006) Strategy \& Society: The Link Between Competitive Advantage and Corporate Social Responsibility, Harvard Business Review, vol. 84, n. 12, pp. 78-92.

Porter M., Kramer M. (2011) Creating Shared Value: How to Reinvent Capitalism-and Unleash a Wave of Innovation and Growth, Harvard Business Review, vol. 89, n. 1/2, pp. 62-77.

Salhofer S., Obersteiner G., Schneider F., Lebersorger S. (2008) Potentials for Prevention of Municipal Solid Waste, Waste Management, vol. 28, n. 2, pp. 245-259.

http://dx.doi.org/10.1016/j.wasman.2007.02.026

Sarkis J., Cordeiro J.J., Vazquez Brust D. (eds.) (2010) Facilitating Sustainable Innovation through Collaboration. A Multi-Stakeholder Perspective, Springer, Netherlands.

Seitanidi M.M. (2007) Intangible economy: How Can Investors Deliver Change in Businesses? : Lessons from Nonprofit-Business Partnerships, Management Decision, vol. 4, n. 5, pp.853-865.

http://dx.doi.org/10.1108/00251740710753675

Seitanidi M.M. and Crane A. (2009) Implementing CSR Through Partnerships: Understanding the Selection, Design and Institutionalisation of Nonprofit-Business Partnerships, Journal of Business Ethics, vol. 85, n. 2 , pp. 413-249.

http://dx.doi.org/10.1007/s10551-008-9743-y

Seitanidi M.M., Ryan A. (2007) A Critical Review of Forms of Corporate Community Involvement: from Philanthropy to Partnerships, International Journal of Nonprofit and Voluntary Sector Marketing, vol. 12, pp. 247-266.

http://dx.doi.org/10.1002/nvsm.306

Selsky J. W., Parker B. (2005) Cross-Sector Partnerships to Address Social Issues: Challenges to Theory and Practice, Journal of Management, vol. 31, n. 6, pp. 1-25. http://dx.doi.org/10.1177/0149206305279601

Selsky J.W., Parker B. (2010) Platforms for Cross-Sector Social Partnerships: Prospective Sensemaking Devices for Social Benefit, Journal of Business Ethics, vol. 94, pp. 21-37. http://dx.doi.org/10.1007/s10551-011-0776-2

Shaw D., Clarke I. (1999) Belief Formation in Ethical Consumer Groups: an Exploratory Study, Marketing Intelligence and Planning, vol. 17, n. 2/3, pp. 109-120.

http://dx.doi.org/10.1108/02634509910260968

Sinha R. (2011) Green Retailing: An Exploratory Study Examining the Effects of Sustainability on Global Retail Landscape, Proceedings of the Conference on Inclusive \& Sustainable Growth Role of Industry, Government and Society, Nagpur, July 15 th $-16^{\text {th }}$.

Spence L., Bourlakis M. (2009) The Evolution from Corporate Social Responsibility to Supply Chain Responsibility: the Case of Waitrose, Supply Chain Management: An International Journal, vol. 14, n. 4, pp. 291-302.

http://dx.doi.org/10.1108/13598540910970126

Stenmarck A., Hanssen O.J., Silvennoinen K., Katajajuuri J-M., PlanMiljö M.W. (2011) Initiatives on Prevention of Food Waste in the Retail and Wholesale Trades, Nordic co-operation, Nordic Council of Ministers, DK.

Stuart T. (2009) Waste - Uncovering the Global Food Scandal, Penguin Books: London, UK. 
Tassinari V. (2010) Retailers, Frontiers of Innovation and Local Legislative Constraints, Symphonya. Emerging Issues in Management (symphonya.unimib.it), n. 1, pp. 18-22.

http://dx.doi.org/10.4468/2010.1.03tassinari

Van Herpen E., Pennings J.M.E., Meulenberg M. (2003) Consumers' Evaluations of Socially Responsible Activities in Retailing, Working Paper Maastricht University, Maastricht, Netherlands.

Waddock, S. A.(1988) Building Successful Partnerships, Sloan Management Review, Summer, pp. 17-23.

Waddock, S. (1989) Understanding Social Partnerships. An Evolutionary Model of Partnership Organisations, Administration \& Society, vol. 21, n. 1, pp. 78-100. http://dx.doi.org/10.1177/009539978902100105

Waddock S. (2008) Building a New Institutional Infrastructure for Corporate Responsibility, Academy of Management Perspectives, vol. 22, n. 3, pp. 87-108.

Whysall P. (2000) Addressing Ethical Issues in Retailing: A Stakeholder Perspective, International Review of Retail Distribution and Consumer Research, vol. 10, n. 3, pp. 305-318. 